\title{
Analysis of Chemical Composition Characteristics and Cause of Formation of Karst Water of Taiyuan Formation in the Lower Part of the Coal Seam in Panxie Mining Area
}

\author{
Tingting Yang ${ }^{1,2}$, Guangquan $\mathrm{Xu}^{1}$ \\ ${ }^{1}$ Technology School of Earth and Environment, Anhui University of Science, Huainan, China \\ ${ }^{2}$ Huainan Mining Industry (Group) Co. Ltd., Huainan, Anhui, China \\ Email:2357813309@qq.com
}

How to cite this paper: Yang, T.T. and $\mathrm{Xu}$, G.Q. (2019) Analysis of Chemical Composition Characteristics and Cause of Formation of Karst Water of Taiyuan Formation in the Lower Part of the Coal Seam in Panxie Mining Area. Open Journal of Geology, 9, 527-537.

https://doi.org/10.4236/ojg.2019.99035

Received: August 27, 2019

Accepted: September 15, 2019

Published: September 18, 2019

Copyright $\odot 2019$ by author(s) and Scientific Research Publishing Inc. This work is licensed under the Creative Commons Attribution International License (CC BY 4.0).

http://creativecommons.org/licenses/by/4.0/

\section{(c) (i) Open Access}

\begin{abstract}
Huainan mining area is located in the southern margin of the North China Plate, which is an important coal-producing base in the eastern part of China, its deep coal seam mining is threatened by karst water inrush disasters in the bottom plate, analyzing hydrogeochemical characteristics and exploring its causes are an important prerequisite for preventing karst water hazards in the coal floor. This paper takes the karst water of the Taiyuan Formation in the lower part of the A-group coal seam of the Xieqiao-Zhangji-Gubei three mines in the Panxie mining area as the research object, and multivariate statistics, hydrochemical analysis were combined with hydrogeochemical simulation. The hydrogeochemical Component characteristics and cause of formation of the karst water-bearing system covered by huge thick unconsolidated layer are discussed. The results show that the cations are dominated by $\mathrm{Na}^{+}+\mathrm{K}^{+}$, and the anions are mainly $\mathrm{Cl}^{-}$and $\mathrm{HCO}_{3}^{-}$in the karst water in Taiyuan Formation in the study area, mainly affected by the dissolution of salt rock and the oxidation of pyrite, there are cations exchange and adsorption and desulfurization.
\end{abstract}

\section{Keywords}

Karst Water of Taiyuan Formation, Ion Combination Ratio, Genetic Effect, Water Chemistry Simulation

\section{Preface}

Energy is one of the important factors supporting the rapid and stable develop- 
ment of China's economy, and coal resources occupy an important dominant position in China's energy structure [1]. The continuous loss of resources accelerates the process of deep mining of coal resources, while deep mining of coal faced with the complex environment of "three highs and one disturbance" [2], complex environment makes the deep mining of coal in China is directly threatened by the karst water damage in the lower part. In recent years, China's karst water disasters frequently occur, causing huge loss of life and property. Therefore, it is particularly important to correctly understand the hydrogeological conditions of the mining area. Hydrogeochemical method is one of the most applications and effective methods to analyze the hydrogeological conditions of research areas.

Group A in Huainan Coalfield is rich in coal resources and good in coal quality. At present, the mining in Panxie mining area is mainly concentrated in the mining areas of Gubei, Zhangji and Xieqiao, but it is vulnerable to karst water damage due to the direct contact between the bottom plate and the lower karst aquifer, and relatively difficult to mines. According to statistics, there have been 19 floor karst water inrush accidents in Huainan coalfield in the past 10 years [3]. Previous studies on hydrogeochemistry in Huainan coalfield mostly focused on water source identification, water chemistry, water flow infiltration and hydrodynamic characteristics [4]-[8], and the study on the genesis of aquifers and the effects on environmental formation less.

Therefore, this paper collects 199 Taiyuan karst water samples from the three mines of Xieqiao-Zhangji-Gubei in the past 10 years, using multivariate statistical analysis, water chemistry (piper diagram, ion ratio) and hydrogeochemical simulation method to analyze its chemical characteristics and to explore the causes in panxie mining area coal seam group A bottom karst water. The research results can provide a theoretical basis for the prevention and control of karst water damage in coal seam of Group A in Huainan coalfield.

\section{Overview of the Study Area}

At present, the coal mining of Group A in Huainan coalfield is mainly concentrated in the three mines of Xieqiao-Zhangji-Gubei in Panxie mining area. The overall east-west and south-north boundary faults of the three mines are changfeng fault, chenqiao fault, fufeng fault, shangtang-minglongshan fault. There are unevenly distributed secondary wide and slow folds and faults in the area, and the overall trend is EW and NNE. The strata in the area belongs to the typical Huainan sedimentary strata, and the bottom to the top is Cambrian, Ordovician, Carboniferous, Permian and Quaternary loose layers. The total thickness of the Taiyuan Formation is 99.99 - $129.11 \mathrm{~m}$, with an average of $113.99 \mathrm{~m}$; limestone, mudstone, siltstone and thin coal are the main components, including 10 - 13 layers of thin layer of limestone. The Initial water level by xie qiao, zhang ji and gu bei during detailed and detailed exploration is all higher than the surface. The karst water level is $23.08-27.06 \mathrm{~m}$; the unit water is 0.0000405 $1.764 \mathrm{~L} / \mathrm{s} \cdot \mathrm{m}$, the water-rich water is weak to medium, and the water temperature 
is $29^{\circ} \mathrm{C}-36.5^{\circ} \mathrm{C}$. It does not touch with the upper cover, and the replenishment conditions are poor.

The aquifers affecting coal mining in group A are mainly coal-series sandstone fissure aquifer, taiyuan inter-layer limestone karst fissure confined aquifer, Ordovician carbonate karst fissure confined aquifer and Cambrian carbon rock karst-fissure confined aquifer. Due to the direct contact between the limestone karst-fissure aquifer in taiyuan formation and the lower coal floor of group A, there is a great potential flood hazard.

There are currently eight pairs of mines in the Panxie mining area that have been put into production, and accumulated more geological and hydrogeological data. There are 4 karst collapse columns measured and 6 suspected, and group A of coal in this area has a large mining prospect. Therefore, it is of great significance to study the chemical composition and genesis of karst fissure water in taiyuan formation at the bottom of group A coal in this area for the prevention and control of karst water damage.

\section{Sampling and Analysis}

A total of 199 karst water samples from the Taiyuan Formation of the lower coal of Group A were collected, and their distribution is shown in Figure 1. The $\mathrm{pH}$, total dissolved solids (TDS), conductivity and water temperature were measured in site; deionized before sampling wash the $1 \mathrm{~L}$ polyethylene bottle 3 times in water, rinse it three times with the sample to be taken, seal the sample, and bring the collected water sample back to the laboratory for routine ion measurement. $\mathrm{HCO}_{3}^{-}$and $\mathrm{CO}_{3}^{2-}$ by acid-base titration, $\mathrm{Cl}^{-}$and $\mathrm{SO}_{4}^{2-}$ by ion chromatography, $\mathrm{Ca}^{2+}$ and $\mathrm{Mg}^{2+}$ using EDTA titration, $\mathrm{K}^{+}+\mathrm{Na}^{+}$was measured by flame atomic absorption spectrophotometry. After testing, the relative error of the anion and cation balance of all water samples is less than $5 \%$, which meets the standard.

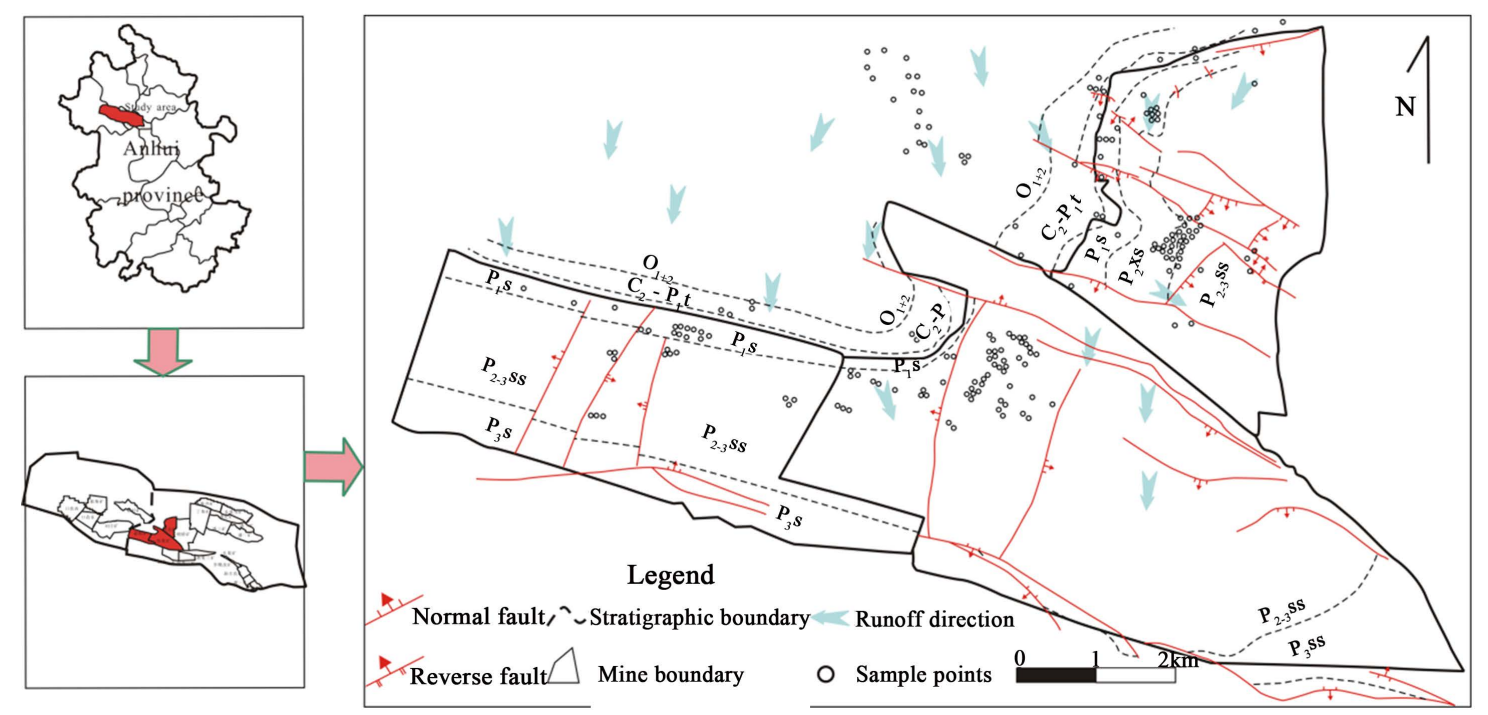

Figure 1. Sampling point distribution map in Xieqiao-Zhangji-Gubei Mine Water of Huainan Coalfield. 


\section{Hydrochemical Characteristics of Karst Water}

\subsection{Statistical Characteristics of Different Components}

Through the statistical analysis of the 199 Taiyuan water samples of the Xieqiao-Zhangji-Gubei mine, the statistical analysis results are shown in Table 1. The total dissolved solids (TDS) content ranges from $708.37 \mathrm{mg} / \mathrm{L}$ to 4061.35 $\mathrm{mg} / \mathrm{L}$, the average value is $2544.43 \mathrm{mg} / \mathrm{L}$, the cations are dominated by $\mathrm{Na}^{+}+\mathrm{K}^{+}$, the $\mathrm{Ca}^{2+}$ ion content is the second, the $\mathrm{Mg}^{2+}$ content is the least; the anion content was mainly $\mathrm{Cl}^{-}$, followed by $\mathrm{HCO}_{3}^{-}, \mathrm{SO}_{4}^{2-}$ and $\mathrm{CO}_{3}^{2-}$, the average $\mathrm{pH}$ value is 8.73 , is alkaline water.

The coefficient of variation is the ratio of the standard deviation to the average. The ions with a coefficient of variation greater than 0.5 are $\mathrm{Ca}^{2+}, \mathrm{Mg}^{2+}$, $\mathrm{SO}_{4}^{2-}, \mathrm{HCO}_{3}^{-}, \mathrm{CO}_{3}^{2-}$, indicating that there is a certain difference in the spatial distribution of each ion content. Among them, the coefficient of variation of $\mathrm{Ca}^{2+}$ and $\mathrm{CO}_{3}^{2-}$ is much higher than 1, indicating that the spatial distribution is more dispersed and the ion concentration varies greatly in space.

The water quality types of karst water in the research area are shown in Figure 2, in which $\mathrm{Na}^{+}+\mathrm{K}^{+}$and $\mathrm{Cl}^{-}$are dominant. The water quality types are mainly distributed in the lower right side of the diamond. The water quality type is mainly $\mathrm{Na}^{+}+\mathrm{K}^{+}, \mathrm{Cl} \cdot \mathrm{HCO}_{3}-\mathrm{Na}+\mathrm{K}, \mathrm{Cl}_{\mathrm{SO}_{4}}-\mathrm{Na}+\mathrm{K}$, respectively accounted for $21.61 \%, 44.22 \%$, and $23.31 \%$, and other water quality types accounted about for $10 \%$.

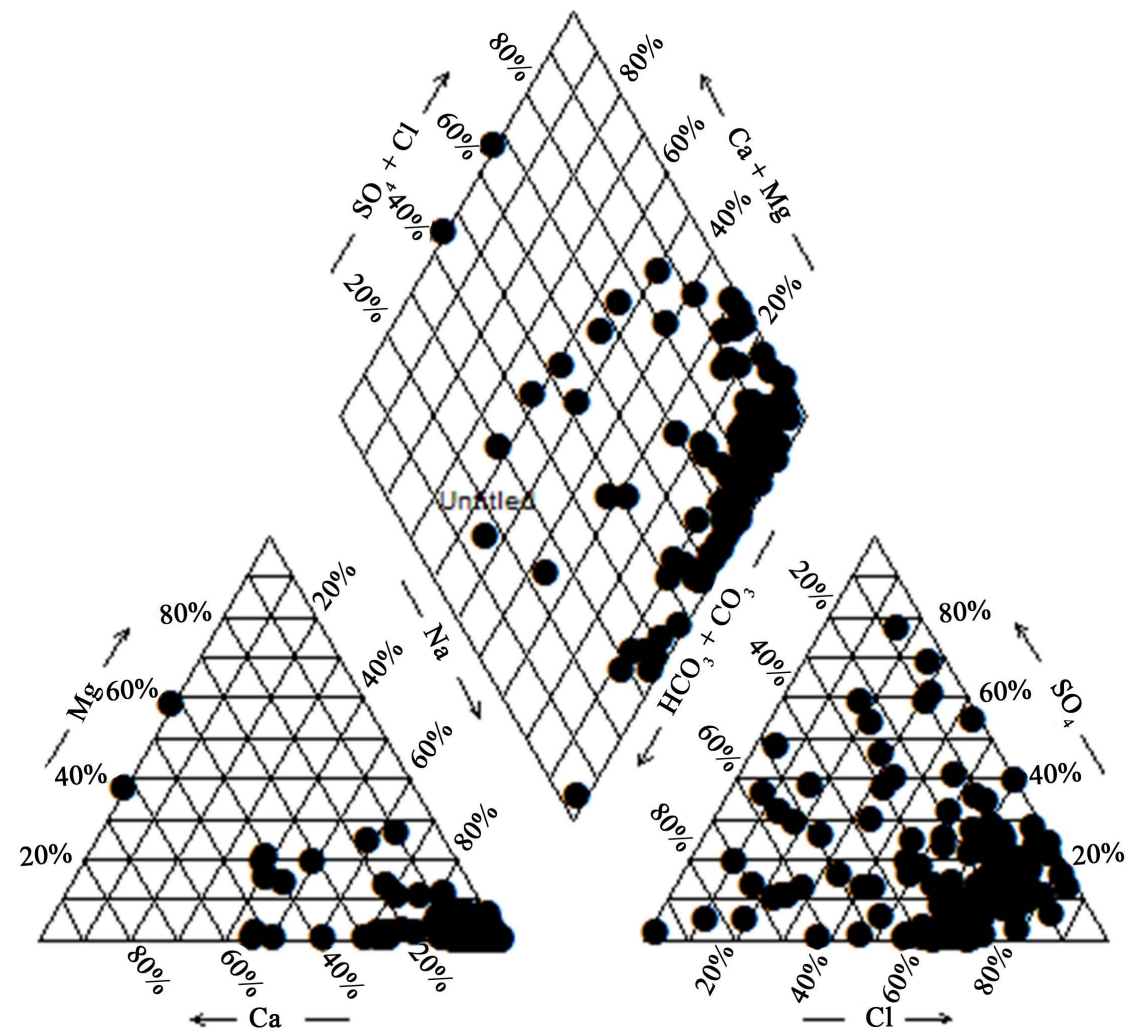

Figure 2. Piper map of research area. 
Table 1. Chemical statistic results of karst water in Taiyuan Formation of study area.

\begin{tabular}{ccccccc}
\hline Parameter & $\begin{array}{c}\text { Maximum } \\
\text { value }\end{array}$ & $\begin{array}{c}\text { Minimum } \\
\text { value }\end{array}$ & $\begin{array}{c}\text { Average } \\
\text { value }\end{array}$ & Median & $\begin{array}{c}\text { Standard } \\
\text { deviation }\end{array}$ & $\begin{array}{c}\text { Coefficient } \\
\text { of variation }\end{array}$ \\
\hline $\mathrm{pH}$ & 13.20 & 7.25 & 8.73 & 8.41 & 1.08 & 0.12 \\
$\mathrm{~K}^{+}+\mathrm{Na}^{+}(\mathrm{mg} / \mathrm{L})$ & 1617.16 & 140.01 & 872.74 & 921.62 & 277.87 & 0.32 \\
$\mathrm{Ca}^{2+}(\mathrm{mg} / \mathrm{L})$ & 941.90 & 4.28 & 51.39 & 34.07 & 100.66 & 1.96 \\
$\mathrm{Mg}^{2+}(\mathrm{mg} / \mathrm{L})$ & 38.67 & 1.19 & 13.51 & 15.56 & 7.68 & 0.57 \\
$\mathrm{Cl}^{-}(\mathrm{mg} / \mathrm{L})$ & 1930.25 & 109.90 & 951.03 & 1024.16 & 266.30 & 0.28 \\
$\mathrm{SO}_{4}^{2-}(\mathrm{mg} / \mathrm{L})$ & 1229.57 & 26.14 & 293.29 & 268.97 & 153.45 & 0.52 \\
$\mathrm{HCO}_{3}^{-}(\mathrm{mg} / \mathrm{L})$ & 2282.15 & 10.79 & 453.92 & 353.90 & 294.16 & 0.65 \\
$\mathrm{CO}_{3}^{2-}(\mathrm{mg} / \mathrm{L})$ & 600.10 & 0.00 & 26.00 & 12.00 & 55.52 & 2.14 \\
$\mathrm{TDS}^{2}(\mathrm{mg} / \mathrm{L})$ & 4061.45 & 708.37 & 2454.43 & 2476.10 & 528.60 & 0.22 \\
\hline
\end{tabular}

\subsection{Spatial Distribution Characteristics of Different Components}

The TDS content in the study area was between $708.37-4061.35 \mathrm{mg} / \mathrm{L}$, and the centralized distribution was between $2000-3000 \mathrm{mg} / \mathrm{L}$. With the deepening, the TDS content increased, as shown in Figure 3(a), and the TDS content (c) with depth $(h)$ the growth relationship is shown in the following Formula (1), which shows that with the increase of depth, the TDS content is continuously accumulated, and the water quality changes further. With the change of depth, $\mathrm{Cl}^{-}$ shows a linear decrease trend, as shown in Figure 3(b), and the ion content is mostly distributed between $750-1250 \mathrm{mg} / \mathrm{L}$. The relationship between the ion content and the depth change between is shown in Equation (2), which indicates that the aquifer may have replenishment; the change trend of ion content of $\mathrm{SO}_{4}^{2-}$ and $\mathrm{HCO}_{3}^{-}$with depth is just the opposite and their distribution is shown in Figure 3(c) and Figure 3(d), with the increase of depth, the content of $\mathrm{SO}_{4}^{2-}$ showed a slow growth trend, and $\mathrm{HCO}_{3}^{-}$showed a slow decreasing trend, indicating that the hydrochemical environment of aquifers is constantly changing with the increase of depth.

According to the above analysis, with the increase of vertical depth, TDS and $\mathrm{SO}_{4}^{2-}$ show an increasing trend, $\mathrm{Cl}^{-}$and $\mathrm{HCO}_{3}^{-}$show a decreasing trend, which is related to the hydrochemical environment where groundwater runoff is, the condition of diameter and discharge, lithology, water and rock action and other factors. When groundwater flows through different areas, water-rock reactions will occur with different minerals, and the content of ions will change correspondingly. The total amount of ions continues to accumulate, but the $\mathrm{Cl}^{-}$ content shows a decreasing trend with the depth, which is related to the situation that the aquifer is dominated by interlayer runoff, but some areas have vertical recharge through cracks. The increase of $\mathrm{SO}_{4}^{2-}$ content and the decrease of $\mathrm{HCO}_{3}^{-}$content are related to the water chemical environment of the aquifer, 


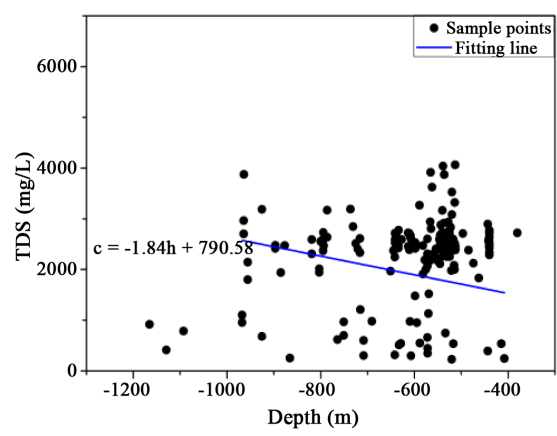

(a)

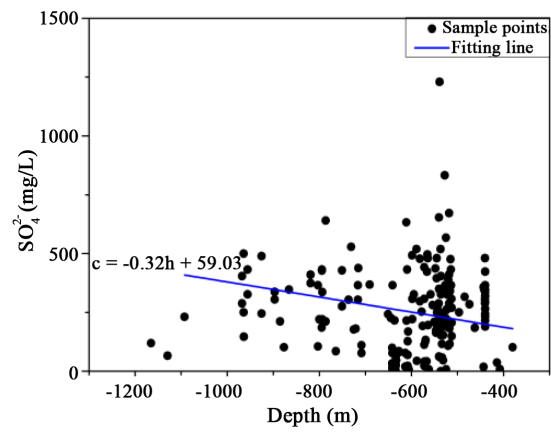

(c)

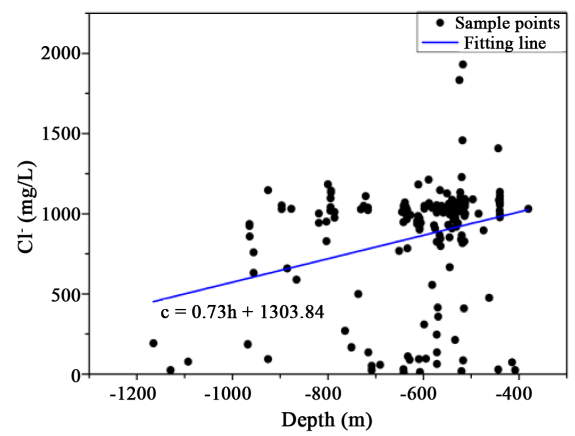

(b)

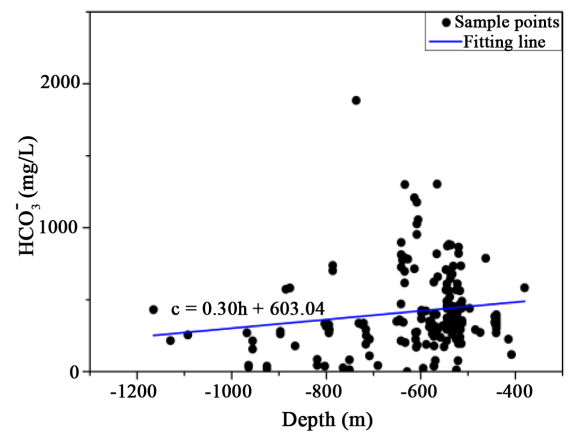

(d)

Figure 3. Relationship between ion content and depth.

the deep mining of the coal seam makes the originally closed reducing environment become a partially open oxidizing environment, which provides corresponding environmental conditions with the chemical reactions of related minerals. Therefore, as the depth increases, the flow rate slows down, the water-rock effect is further sufficient, and the water chemical environment is further changed, so that the contents of TDS, $\mathrm{Cl}^{-}, \mathrm{SO}_{4}^{2-}$ and $\mathrm{HCO}_{3}^{-}$in the aquifer are spatially Make a certain change.

$$
\begin{aligned}
& c=-1.84 h+790.58 \\
& c=0.73 h+1303.84
\end{aligned}
$$

\section{Genetic Analysis}

\subsection{Genetic Effect}

\subsubsection{Dissolution}

According to the ratio of $\mathrm{HCO}_{3}^{-} /\left(\mathrm{SO}_{4}^{2-}+\mathrm{Cl}^{-}\right)$, the specific conditions of dissolution of carbonate rock and salt rock in aquifer can be judged [9]. As shown in Figure $4(\mathrm{a})$, the ratio of $\mathrm{HCO}_{3}^{-} /\left(\mathrm{SO}_{4}^{2-}+\mathrm{Cl}^{-}\right)$in the water sample of the study area falls below the 1:1 line, and a few are above the line, indicating that the aquifer is mainly dissolved by salt rock and contains a small amount of carbonate rock to dissolve. The taiyuan formation in the lower part of group A coal seam is mainly composed of salt rock and calcite, with less dolomite content. Therefore, the dissolution of this area is mainly caused by the dissolution of salt rock. 


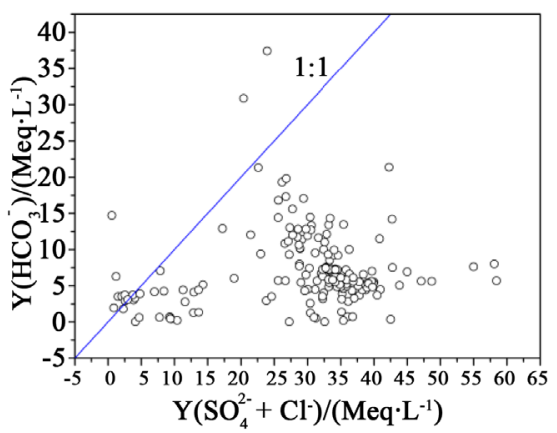

(a)

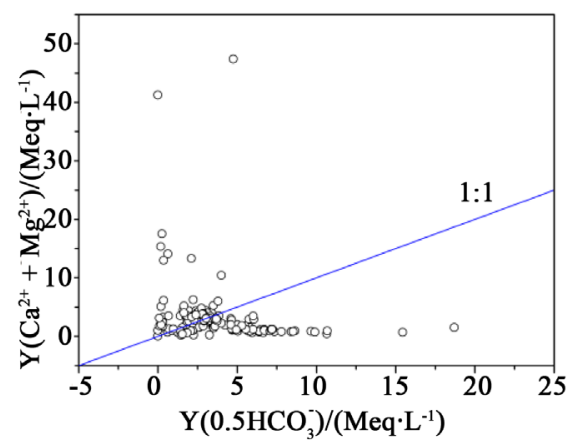

(c)

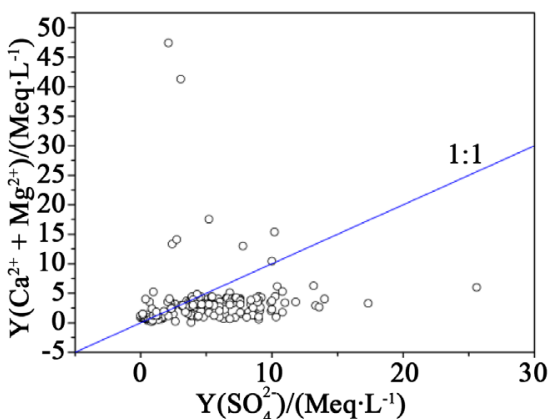

(b)

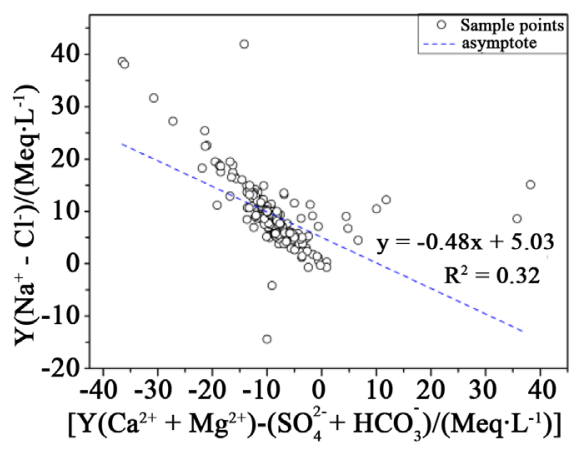

(d)

Figure 4. Main ion ratio map of Karst water in study area.

According to the ratio of $\left(\mathrm{Ca}^{2+}+\mathrm{Mg}^{2+}\right) / \mathrm{SO}_{4}^{2-}$, the source of $\mathrm{Ca}^{2+}, \mathrm{Mg}^{2+}$ and $\mathrm{SO}_{4}^{2-}$ ions in the aquifer can be determined [10]. As shown in Figure 4(b), some water samples fall near the line 1:1, indicating that the dissolution of sulfate in the aquifer is not the only source of $\mathrm{Ca}^{2+}, \mathrm{Mg}^{2+}$, and may be derived from the dissolution of carbonate, the ratio of some water samples is much less than 1 , indicating that there are other sources of $\mathrm{SO}_{4}^{2-}$ in the aquifer. The Taiyuan Formation in Huainan Mining Area has less sulfate and more pyrite, so the sulfate is mostly derived from pyrite. The oxidation of the equation is:

$$
4 \mathrm{FeS}_{2}+15 \mathrm{O}_{2}+14 \mathrm{H}_{2} \mathrm{O} \rightarrow 4 \mathrm{Fe}(\mathrm{OH})_{3} \downarrow+8 \mathrm{SO}_{4}^{2-}+16 \mathrm{H}^{+}
$$

The aquifer is entirely in a reducing environment as a whole, but due to deep coal seam mining, the aquifer becomes a partially open oxidizing environment, allowing gases such as $\mathrm{O}_{2}$ and $\mathrm{CO}_{2}$ enter the aquifer, thus enabling pyrite to generate $\mathrm{SO}_{4}^{2-}$ under the action of oxygen and water.

\subsubsection{Desulfurization}

According to the relationship between the ratio of $\left(\mathrm{Ca}^{2+}+\mathrm{Mg}^{2+}\right) /\left(0.5 \mathrm{HCO}_{3}^{-}\right)$ and the line 1:1, the sources of $\mathrm{Ca}^{2+}, \mathrm{Mg}^{2+}$ and $\mathrm{HCO}_{3}^{-}$ions in aquifers can be inferred [10], it can be seen from Figure 4(c) that the water sample points in the aquifer are distributed on both sides of the 1:1 line, indicating that the dissolution of carbonate rocks is not the only source of $\mathrm{Ca}^{2+}, \mathrm{Mg}^{2+}$ and $\mathrm{HCO}_{3}^{-}$, according to the spatial distribution of the water chemical components in the previous

section, the $\mathrm{HCO}_{3}^{-}$ion content in the aquifer is concentrated in the position of 
$-500--700 \mathrm{~m}$, and the whole is in a closed reduction environment, making $\mathrm{SO}_{4}^{2-}$ ions produce $\mathrm{HCO}_{3}^{-}$under the action of desulfuric bacteria.

\subsubsection{Cation Exchange and Adsorption}

Different cations in groundwater will alternately adsorb under certain conditions, according to $\left(\mathrm{Na}^{+}-\mathrm{Cl}^{-}\right) /\left[\gamma\left(\mathrm{Ca}^{2+}+\mathrm{Mg}^{2+}\right)-\gamma\left(\mathrm{SO}_{4}^{2-}+\mathrm{HCO}_{3}^{-}\right)\right]$is close to -1 to determine the strength of its alternate adsorption [11]. As shown in Figure $4(\mathrm{~d})$, the slope of the asymptote of the water sample in the study area is -0.48 , and the negative correlation is weak, indicating that there is alternating adsorption of cations in the aquifer, but its effect is not obvious.

\subsection{Simulation Analysis}

The reverse simulation in the reaction path can verify the chemical reaction and composition of the material in the aquifer from the reverse [12] [13] [14]. Aquifer in the study area do bedding movement from north to south, Therefore, according to the run-off path of the study area (Figure 5), E121 is selected as the starting point and E157 is used as the termination point. The specific data is shown in Table 2, and the simulation software is used to calculate the saturation index, the results are shown in Table 3, it can be seen that the saturation index of vermiculite, calcite and dolomite in the aquifer is greater than 0 , indicating that it is saturated in the aquifer; anhydrite, $\mathrm{CO}_{2}$, rock salt and $\mathrm{O}_{2}$ are all less than 0 and are in a dissolved state. On the run-off path, the saturation index of calcite, vermiculite, dolomite, anhydrite and gypsum is continuously decreasing, indicating that the water-rock interaction along the way is continuing.

Calculate the saturation index and the geological data of the mining area, and determine the "possible mineral phase" required for the simulation as calcite, dolomite, pyrite, salt rock, $\mathrm{O}_{2}, \mathrm{CO}_{2}, \mathrm{H}_{2} \mathrm{~S}, \mathrm{Fe}(\mathrm{OH})_{3}$ and a cation exchanger $(\mathrm{NaX}$, $\left.\mathrm{CaX}_{2}\right)$.

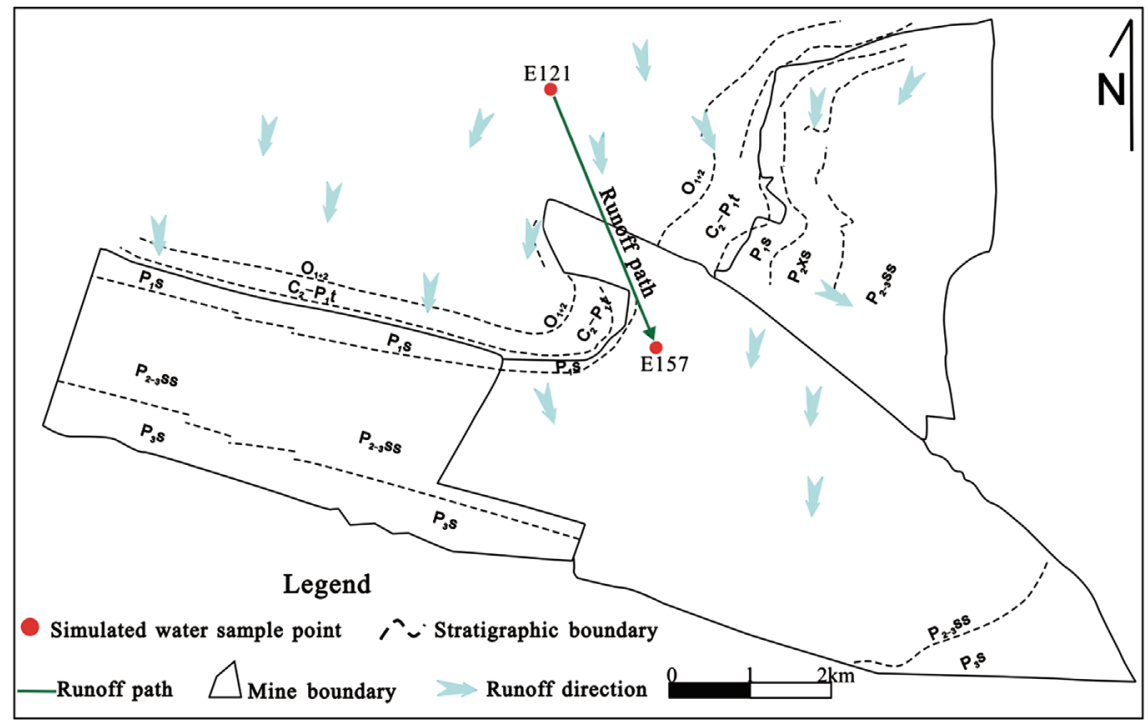

Figure 5. Map of reverse simulation path in study area. 
From this, the inversion simulation results are shown in Table 4. From the table, it can be seen that the $\mathrm{CaCO}_{3}$ value is less than 0 , and the $\mathrm{CaMg}\left(\mathrm{CO}_{3}\right)_{2}$ is greater than 0 , indicating that calcite precipitation and dolomite dissolution occur in the aquifer of the study area, the phenomenon of dolomite dissolution is different from the calculation of the saturation index, which is related to the phenomenon of "non-conformity dissolution" in this area [15]. In this area, rock salt dissolution occurred mainly along the runoff path, and the contents of $\mathrm{Cl}^{-}$ and $\mathrm{Na}^{+}$increased, but cation exchange, dissolved $\mathrm{CaX}$, precipitated $\mathrm{NaX}$, decreased $\mathrm{Na}^{+}$, and increased $\mathrm{Ca}^{2+}$ content. The sum of the cation exchange and the precipitation of calcite is still less than the dissolved amount of rock salt. Therefore, $\mathrm{Na}^{+}$is still growing, but the content is less than $\mathrm{Cl}^{-}$content; $\mathrm{FeS}_{2}$ and $\mathrm{O}_{2}$ are dissolved, $\mathrm{Fe}(\mathrm{OH})_{3}$ is in a precipitated state, without the production of $\mathrm{H}_{2} \mathrm{~S}$ gas, indicating that the oxidation of pyrite occurs in the aquifer, and the content of $\mathrm{SO}_{4}^{2-}$ increases, but the desulfurization is not very obvious. From this, it can be inferred that the leaching action mainly occurs in the aquifer, and there are alternating cation adsorption and desulfurization, which is consistent with the analysis results above.

Table 2. Hydrochemiscal data of the simulation points in different zones from different aquifers.

\begin{tabular}{cccccccccc}
\hline $\begin{array}{c}\text { Parameter } \\
\text { number }\end{array}$ & $\mathrm{pH}$ & $\begin{array}{c}\mathrm{K}^{+}+\mathrm{Na}^{+} \\
(\mathrm{mg} / \mathrm{L})\end{array}$ & $\begin{array}{c}\mathrm{Ca}^{2+} \\
(\mathrm{mg} / \mathrm{L})\end{array}$ & $\begin{array}{c}\mathrm{Mg}^{2+} \\
(\mathrm{mg} / \mathrm{L})\end{array}$ & $\begin{array}{c}\mathrm{Cl}^{-} \\
(\mathrm{mg} / \mathrm{L})\end{array}$ & $\begin{array}{c}\mathrm{SO}_{4}^{2-} \\
(\mathrm{mg} / \mathrm{L})\end{array}$ & $\begin{array}{c}\mathrm{HCO}_{3}^{-} \\
(\mathrm{mg} / \mathrm{L})\end{array}$ & $\begin{array}{c}\mathrm{CO}_{3}^{2-} \\
(\mathrm{mg} / \mathrm{L})\end{array}$ & $\begin{array}{c}\mathrm{TDS} \\
(\mathrm{mg} / \mathrm{L})\end{array}$ \\
\hline E121 & 8.98 & 738.35 & 10.37 & 6.30 & 658.79 & 211.33 & 572.29 & 24.61 & 1935.97 \\
E157 & 8.1 & 896.13 & 56.99 & 14.36 & 1066.69 & 360.47 & 302.96 & - & 2560.00 \\
\hline
\end{tabular}

Table 3. Mineral saturation index SI of the water sample points in Taiyuan formation.

\begin{tabular}{ccccccccc}
\hline $\begin{array}{c}\text { Parameter } \\
\text { Sample points }\end{array}$ & Anhydrite & Aragonite & Calcite & $\mathrm{CO}_{2}$ & Gypsum & $\begin{array}{c}\text { rock } \\
\text { salt }\end{array}$ & $\begin{array}{c}\mathrm{O}_{2} \\
(\mathrm{~g})\end{array}$ & Dolomite \\
\hline E121 & -2.61 & 0.53 & 0.68 & -9.36 & -2.39 & -5.00 & -19.82 & 1.16 \\
E157 & -1.69 & 0.46 & 0.60 & -2.69 & -1.47 & -4.72 & -34.79 & 0.96 \\
\hline
\end{tabular}

Table 4. Summary of simulation results of karst water simulation path in Taiyuan formation (unit: $10^{-3} \mathrm{mmol} / \mathrm{L}$ ).

\begin{tabular}{cccc}
\hline Parameter & Results & Parameter & Results \\
\hline Starting point & $\mathrm{E} 121$ & $\mathrm{CaX}_{2}$ & 2.153 \\
Ending point & $\mathrm{E} 157$ & $\mathrm{CO}_{2}$ & 5.198 \\
$\mathrm{CaCO}_{3}$ & -1.321 & $\mathrm{H}_{2} \mathrm{~S}$ & - \\
$\mathrm{CaMg}\left(\mathrm{CO}_{3}\right)_{2}$ & 0.3309 & $\mathrm{O}_{2}$ & 2.915 \\
$\mathrm{NaCl}$ & 10.96 & $\mathrm{Fe}(\mathrm{OH})_{3}$ & -0.777 \\
$\mathrm{NaX}$ & -4.306 & $\mathrm{FeS}_{2}$ & 0.777
\end{tabular}

Note: Positive values represent the amount of dissolution, negative values indicate the amount of precipitation, indicating that there is no such value in the simulation calculation. 


\section{Conclusions}

Through the analysis of the chemical characteristics and genesis of the karst water in the coal of group A in the study area, the following conclusions are drawn:

1) The karst water cations of Taiyuan Formation are dominated by $\mathrm{Na}^{+}+\mathrm{K}^{+}$, followed by $\mathrm{Ca}^{2+}, \mathrm{Mg}^{2+}$, and the anions of $\mathrm{Cl}^{-}$and $\mathrm{HCO}_{3}^{-}$. The ion content is $\mathrm{Cl}^{-}>\mathrm{HCO}_{3}^{-}>\mathrm{SO}_{4}^{2-}>\mathrm{CO}_{3}^{2-}$;

2) According to the relationship of ion ratio, it is known that the leaching effect mainly occurs in the karst aquifer of Taiyuan Formation, the dissolution of rock salt and the oxidation of pyrite are dominant, and desulfurization and cation alternate adsorption are present;

3) The water chemistry occurring in the aquifer was reversed by the runoff path in the simulation software, and the results were consistent with the previous genetic analysis, which also confirmed the rationality of the above analysis from the side.

\section{Conflicts of Interest}

The authors declare no conflicts of interest regarding the publication of this paper.

\section{References}

[1] Li, K. (2007) Energy Conservation and Emission Reduction: Coal Enterprises Break New Ground. China Coal Industry, 7, 7-8.

[2] He, M.C., Xie, H.P., Peng, S.P., et al. (2007) Research on Rock Mechanics and Engineering Disaster Control in Deep Mining. Coal Mine Support, No. 3, 1-14.

[3] Zhang, D.D. (2017) Study Oil Water Chemistry Characteristics and Water Source Discrimination Model in Huainan Mining Area. Anhui University of Science and Technology, Huainan.

[4] Li, T., Li, W.P., Gao, Y., et al. (2010) Characteristics of Karst-Fissure Water Bodies Deeply Seated in the Floor of No. 6 Coal Seam in Yangzhuang Coal Mine. Journal of Mining \& Safety Engineering, 27, 98-103.

[5] Ma, L., Qian, J.Z., Zhao, W.D., et al. (2013) Multivariate Statistical Analysis of Chemical Characteristics of Groundwater in Gubei Coal Mine. Journal of Hefei University of Technology, No. 12, 1495-1498.

[6] Chu, T.T., Ge, T., Liu, G.J., et al. (2014) Coal Group A Floor Limestone Component Structure and Hydrochemical Characteristics in Xieqiao Coalmine, Huainan Mining Area. Coal Geology of China, No. 3, 27-31.

[7] Zhang, L., Xu, G.Q., Liu, Z.G., et al. (2010) Water Quality Characteristics and Formation Mechanism of Limestone Water in Coal Seam of Group A. Coal Engineering, 1, 60-63.

[8] Zhang, L. (2010) Hydrogeological Characteristics and Evaluation of Dredging in Deep Karst-A Case Study of Xieyi Coal Mine. Anhui University of Science and Technology, Huainan.

[9] Yu, Y.L., Song, X.F., Guo, J., et al. (2017) Characteristics and Controlling Factors of Water Chemistry in Surface Waters in the Yellow River Delta. Journal of Arid Land Resources and Environment, No. 10, 58-64.

[10] Chen, L.W., Xu, D.Q., Yin, X.X., et al. (2017) Analysis on Hydrochemistry and Its 
Control Factors in the Concealed Coal Mining Area in North China: A Case Study of Dominant Inrush Aquifers in Suxian Mining Area. Journal of China Coal Society, 42, 996-1004.

[11] Luan, F.J., Zhou, J.L., Jia, R.L., et al. (2017) Hydrochemical Characteristics and Formation Mechanism of Groundwater in Plain Areas of Barkol Yiwu Basin, Xinjiang. Environmental Chemistry, 36, 380-389.

[12] Matthew, M.U. and John, M.S. (2001) Tracing Regional Flov Paths to Major Springs in Trans-Pecos Texas Using Geochemical Data and Geochemical Models. Chemical Geology, 179, 53-72. https://doi.org/10.1016/S0009-2541(01)00315-1

[13] Meng, S.X. and Maynard, J.B. (2001) Use of Statistical Analysis to for Mulate Conceptual Models of Geochemical Behavior: Water Chemical Data from the Botucatu Aquifer in Sao Paulo State. Brazilian Journal of Hydrology, 250, 78-97. https://doi.org/10.1016/S0022-1694(01)00423-1

[14] Kenoyer, G.J. and Bowler, C.J. (1992) Groundwater Chemical Evolution in a Sandy Silicate Aquifer in Northern Wisconsin: 2. Reaction Modeling. Water Resources Research, 28, 591-600. https://doi.org/10.1029/91WR02303

[15] Qian, H. and Ma, Z.Y. (2005) Hydrogeochemistry. Geological Publishing House. 